\title{
Hypothalamic regulation of bone
}

\author{
Frank Driessler ${ }^{1}$ and Paul A Baldock ${ }^{1,2}$ \\ ${ }^{1}$ Neuroscience Program, Garvan Institute of Medical Research, St Vincent's Hospital, Sydney 2010, New South Wales, Australia \\ ${ }^{2}$ Faculty of Medicine, University of New South Wales, Sydney 2052, New South Wales, Australia \\ (Correspondence should be addressed to P A Baldock who is now at Bone and Mineral Research Program, Garvan Institute of Medical Research, \\ 384 Victoria Street, Darlinghurst, Sydney, New South Wales 2010, Australia; Email: p.baldock@garvan.org.au)
}

\begin{abstract}
On initial inspection, bone remodeling, the process whereby the skeleton adapts through time, appears to be relatively simple. Two cell types, the bone-forming osteoblasts and the bone-resorbing osteoclasts, interact to keep bone mass relatively stable throughout adult life. However, the complexity of the regulatory influences on these cells is continuing to expand our understanding of the intricacy of skeletal physiology and also the interactions between other organ systems and bone. One such example of the broadening of understanding in this field has occurred in the last decade with study of the central, neural regulation of bone mass. Initial studies of an adipose-derived hormone, leptin, helped define a direct, sympathetic pathway involving efferent neural signals from the hypothalamus to receptors on the osteoblast. Since the leptin-mediated pathway has been continuously modified to reveal a complex system involving neuromedin $U$, cocaineand amphetamine-related transcript and serotonin interacting within the hypothalamus and brainstem to regulate both bone formation and resorption in cancellous bone, a number of other systems have also been identified. Neuropeptide $\mathrm{Y}$, acting through hypothalamic Y2 receptors, is capable of skeleton-wide modulation of osteoblast activity, with important coordination between body weight and bone mass. Cannabinoids, acting through central cannabinoid receptor 1 and bone cell cannabinoid receptor 2 receptors, modulate osteoclast activity, thereby identifying pathways active on both aspects of the bone remodeling process. This review explores the key central pathways to bone and explores the complexity of the interactions being revealed by this emergent field of research.
\end{abstract}

Journal of Molecular Endocrinology (2010) 45, 175-181

\section{Function of hypothalamus}

The brain has long been appreciated as a pivotal regulator of homeostasis in peripheral tissues, including the skeleton. There is now clear evidence for crosstalk between the brain and bone through two distinct routes. The first pathway comprises welldefined hormonal signals arising from neuroendocrine neurons of the hypothalamus and subsequently processed within the pituitary. The second pathway consists of efferent neuronal discharges originating from the hypothalamus and processed through the brainstem. The hypothalamus, with its semipermeable blood-brain barrier, is thus one of the most powerful regulatory regions within the body, integrating signals not only from peripheral tissues but also from within the brain itself. These direct, neural pathways represent an emergent area of study that is identifying novel regulatory axes between the brain and the cells of bone. Moreover, this work is also providing insights into regulatory connections involving skeletal tissue, which are proving to be unexpected, thereby outlining a level of interconnectedness that has been previously unappreciated. This review examines the expanded understanding of the central, neural outputs to bone metabolism and remodeling.

\section{An adipocyte hormone represses bone formation: leptin actions in cancellous bone}

The first model to define a central, neural pathway to bone involved the action of an endocrine signal not from bone, but from fat cells. Leptin, a peptide hormone secreted by adipocytes, signals within the hypothalamus to control body weight. Circulating leptin acts within the hypothalamus as an adipostat, altering appetite and energy expenditure (Boden et al. 1996). Interestingly, leptin-deficient $o b / o b$ mice exhibit a phenotype with varied skeletal abnormalities. Cancellous bone mass is increased despite hypogonadism and hypercortisolism, while, in contrast, bone length and mass are reduced despite markedly greater fat mass compared to wild-type mice (Ducy et al. 2000,

DOI: 10.1677/JME-10-0015 Online version via http://www.endocrinology-journals.org 
Hamrick et al. 2005, Baldock et al. 2006, Iwaniec et al. 2007). Additional models with altered serum leptin levels confirmed the effect of leptin on bone; cancellous bone mass was reduced in leptin transgenic mice and increased in hypoleptinemic A-ZIP lipodystrophic mice (Elefteriou et al. 2004). Moreover, leptin replacement corrected the skeletal phenotype of $o b / o b$ mice by either peripheral or central routes (Ducy et al. 1996, Elefteriou et al. 2004, Wolf 2008). Importantly, centrally administered leptin was able to correct the $o b / o b$ changes in cancellous bone at inactive doses when administered peripherally, indicating a pathway confined to the brain (Ducy et al. 2000). Chemical lesion of neurons in the ventromedial hypothalamus recapitulated the $o b / o b$ phenotype, and abrogated the effect of central leptin administration, localizing the pathway to this nucleus of the hypothalamus (Takeda et al. 2002). This central afferent pathway to bone was subsequently shown to regulate sympathetic tone and thereby modulate adrenergic signaling locally via osteoblastic $\beta 2$ adrenergic receptor ( $\beta 2$ AR; Takeda et al. 2002). Mice that are null for $\beta 2$ AR displayed increased cancellous bone mass and formation, similar to $o b / o b$ mice, and moreover, they were resistant to central leptin administration (Takeda et al. 2002). For the first time, this series of experiments defined a central, neural pathway acting from the hypothalamus directly to the cells of bone. Moreover, the adipose origin of the circulating mediator of this pathway identified a novel regulation between bone and energy homeostasis.

\section{Involvement of the brainstem: brain-derived serotonin}

Recent studies have further expanded our understanding of the leptin pathway to bone, elucidating an important role for serotonin production in the brainstem. Leptin inhibition of bone mass accrual requires the integrity of specific hypothalamic neurons (Takeda $\mathrm{et}$ al. 2002). However, loss of the leptin receptors from these neurons did not affect leptin action (Balthasar et al. 2004), suggesting that direct leptin signaling acts elsewhere in the brain to achieve these functions. Yadav $e t$ al. (2009) have shown that serotonin, produced locally within the brainstem (brain-derived serotonin, BDS) in an isolated circuit from that of the circulatory serotonin, is able to modulate leptin's effects on bone mass.

Serotonin acts via a multiple receptor (HTR) of receptors to modulate numerous processes. These actions have now been expanded to include the regulation of bone mass (Yadav et al. 2009). The marked effects of leptin deficiency on the bone and energy homeostasis were corrected by specific inactivation of serotonin production in the brainstem, while loss of the leptin receptor in serotonergic neurons in the brainstem recapitulates them. Specifically, central serotonin stimulates bone mass accrual through binding to HTR2C receptors on ventromedial hypothalamic neurons and appetite via HTR1A and 2B receptors on arcuate neurons. Thus, leptin inhibits these functions by reducing serotonin synthesis and firing of serotonergic neurons. Thus, leptin and serotonin have opposing actions on bone mass, with leptin's influence on bone mass, at least in cancellous bone, involving the modulation of central serotonin signaling, with a common mechanism regulating energy homeostasis (Fig. 1).

\section{Another step in the pathway: neuromedin U}

Subsequent to the initial studies outlining the central effects of leptin on bone mass, a number of studies have identified additional aspects of the pathway that have expanded our appreciation of the breadth and complexity of central osteo-modulatory signaling. One such discovery involved the actions of neuromedin $\mathrm{U}$ (NMU). NMU is a neuropeptide expressed in hypothalamic neurons and in the small intestine, and is regulated by sympathetic activation (Brighton et al. 2004). However, it has also been shown to regulate bone mass. NMU null mice display increased bone formation and bone mass via a central, hypothalamic pathway (Sato et al. 2007). NMU2 receptor is expressed in the paraventricular nucleus, and central infusion of NMU rescued the high bone mass of NMU null mice. Moreover, NMU and its receptors are not detectable in bone, and osteoblast activity is not altered by in vitro NMU treatment. Interestingly, NMU treatment was

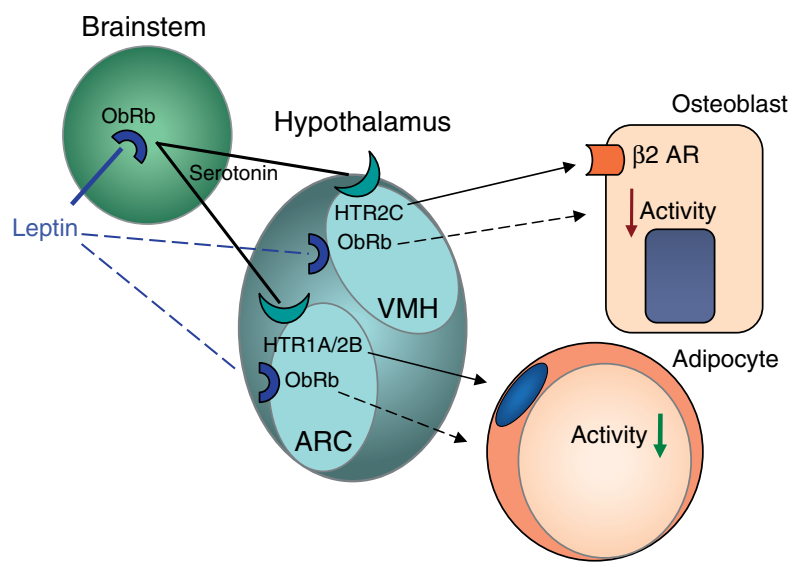

Figure 1 Model of leptin and serotonin signaling in the regulation of bone and fat formation. Leptin modulates bone mass through receptors $(\mathrm{ObRb})$ in the brainstem, which stimulate serotonergic neurons. Subsequent serotonin binding to HTR2C receptors on VMH neurons alters bone mass, and $\mathrm{HTR} 1 \mathrm{~A}$ and $2 \mathrm{~B}$ receptors on $A R C$ neurons alter appetite. The activity of $O b R b$ in these nuclei is an open question. 
found to decrease the high cancellous bone mass of leptin-deficient mice, suggesting a role for NMU downstream of leptin to regulate bone formation. Consistent with this hypothesis, NMU-deficient mice were resistant to the skeletal effects of leptin and $\beta 2 \mathrm{AR}$ agonists. NMU signaling thus begins to outline the mechanistic framework involved in the transmission of the regulatory signals beginning with circulatory leptin and ending with altered bone cell activity (Fig. 2).

\section{Leptin regulation of bone resorption: cocaine- and amphetamine-regulated transcript}

In addition to signals regulating the activity of bone formation, central neural signaling has been shown to alter bone resorption. Cocaine- and amphetamineregulated transcript (CART), a neuropeptide precursor protein involved in the regulation of food intake and energy expenditure, is broadly expressed in the hypothalamus and the peripheral organs such as the pancreas and adrenal glands (Elefteriou et al. 2005). Interestingly, the phenotype of $o b / o b$ mice suggested that leptin could be affecting bone resorption via central effects on CART. $o b / o b$ mice can be distinguished from the $\beta 2 \mathrm{AR}$ null mice by their decrease in hypothalamic CART expression and their increased resorption, thereby implicating CART as a potential regulator of bone resorption. Furthermore, the decreased CART expression in $o b / o b$ mice can be restored by i.p. treatment with leptin (Kristensen et al. 1998). Consistent with this hypothesis, CART knockout mice are osteoporotic due to an increase in bone resorption (Elefteriou et al. 2005). Moreover, CARTdeficient mice express higher levels of RANKL in bone than wild-type mice, with in vitro osteoclast differentiation experiments indicating that the effect of CART on bone is not cell autonomous, suggesting a local mechanism for the central CART changes

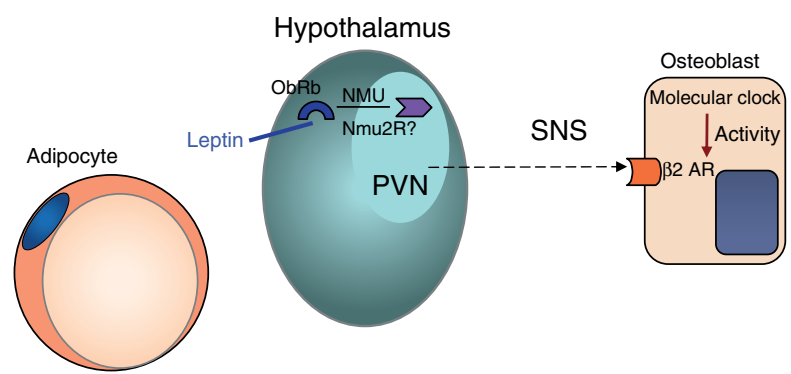

Figure 2 Model of neuromedin $U$ signaling in the regulation of bone formation. As a central regulator of a leptin-dependent regulation of bone mass, neuromedin $U$ acts in the central nervous system downstream of leptin. Efferent sympathetic signaling through the sympathetic nervous system (SNS) affects the molecular clock in bone to regulate bone remodeling.

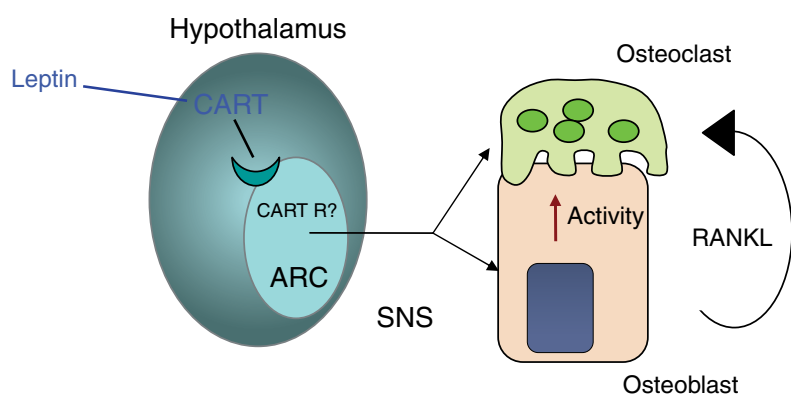

Figure 3 Model of CART signaling in the regulation of bone remodeling. CART expression is altered in proportion to serum leptin levels. Low CART expression induces an increase in bone resorption through higher levels of RANKL, while increased hypothalamic CART expression produces a higher bone mass phenotype.

(Elefteriou et al. 2005). Conversely, increased hypothalamic CART expression in melanocortin 4 receptor null mice has been shown to be necessary for their reduced bone resorption (Elefteriou et al. 2005, Ahn et al. 2006). Thus, in addition to neuro-osteoblastic effects, osteoclastogenesis and bone resorption also appear to be under the control of central neural mediators. At this stage, many studies have produced information about the regulation, the location, processing, and functions of the CART peptide. However, additional studies are needed at elucidating the physiological role and importantly at characterizing the receptor of CART (Fig. 3).

\section{A second central pathway to bone: the neuropeptide $Y$ system}

Another major contributor to the neural output from the hypothalamus to bone is the neuropeptide Y (NPY) system. The NPY system involves three ligands, NPY and two ligands expressed in the periphery, peptide YY, and pancreatic polypeptide. These ligands signal through five receptor subtypes, Y1, Y2, Y4, Y5, and Y6 in mice, expressed widely in central and peripheral tissues (Blomqvist \& Herzog 1997, Lin et al. 2005). NPY is one of the most common neuropeptides in the brain, with strong expression in the hypothalamus. NPY is synthesized in neurons whose cell bodies lie in the arcuate nucleus with projections into surrounding hypothalamic structures. NPY is also co-secreted with norepinephrine in peripheral sympathetic neurons (Bernet et al. 1998). To date, analysis of brain-specific NPY overexpression and Y receptor knockout models has revealed a powerful anti-anabolic pathway involving hypothalamic Y2 receptors and nonhypothalamic Y1 receptors.

The first in vivo indication for the role of NPY in regulation of bone metabolism was demonstrated 
in a murine $\mathrm{Y} 2$ receptor null model. These mice displayed a generalized increase in osteoblast activity in cortical and cancellous bone, with no indication of changes in bone resorption (Baldock et al. 2002). Importantly, this effect was recapitulated by conditional deletion of Y2 receptors from the arcuate nucleus in mature mice, with osteoblast activity elevated up to sevenfold compared to Y2-intact mice (Baldock et al. 2002). While Y2 deletion altered some aspects of endocrine function, such as increasing serum corticosterone levels (Allison et al. 2006), none of these changes was consistent with the increase in bone formation. This finding therefore indicated that the changes in bone homeostasis observed in hypothalamus-specific Y2 receptor-deficient mice were the result of an efferent neural pathway from the hypothalamus, rather than through altered pituitary outflow.

\section{Central involvement in the body weight bone mass relationship?}

Despite early reports of no effect (Elefteriou et al. 2003), a recent study has confirmed the role of NPY in skeletal metabolism. NPY null mice demonstrated a generalized bone anabolic phenotype (Baldock et al. 2009), without significant changes in body weight, similar to that reported for Y2 receptor null mice. The negative relationship between hypothalamic NPY and bone formation is consistent with previous reports of reduced bone formation following overexpression of NPY in the hypothalamus of wild-type mice (Baldock et al. 2005). Interestingly, central NPY overexpression, a model of forced central starvation, similar to that evident in $o b / o b$ mice (Sainsbury et al. 2002), resulted in a reduction in bone mass despite marked increases in body weight, also evident in $o b / o b$. In this manner, as calorie restriction reduces body weight, central NPY levels rise (Lauzurica et al. 2010) and bone formation is inhibited, conserving limited energy resources. Conversely, under excessive calorie intake, body weight increases, NPY expression is reduced, and bone formation is stimulated, thereby matching bone mass to body mass, one of the most fundamental relationships in skeletal physiology. Thus, the central perception of body weight, as evident by alterations in central NPY, may match body weight to bone mass in concert with the well-described mechanical responses.

In addition to the central actions in the hypothalamus, NPY appears to provide a local circuit in the osteoblast. Analysis of Y1 receptor null mice revealed a similar bone phenotype to the high bone mass evident in NPY and Y2 null mice, although with an additional increase in bone resorption (Baldock $e t$ al. 2007). However, in contrast to the hypothalamusspecific action of $\mathrm{Y} 2$ receptors on bone, deletion of $\mathrm{Y} 1$ receptors from the hypothalamus had no effect on bone cell activity or bone volume, indicating that the effects of $\mathrm{Y} 1$ receptors on bone metabolism are mediated by nonhypothalamic receptors (Baldock et al. 2007). While it is possible that $\mathrm{Y} 1$ receptors in regions of the brain other than the hypothalamus may be involved in mediating actions of NPY on bone, a direct effect of NPY on osteoblastic cells acting via locally expressed Y1 receptors is more likely. This is supported by in situ hybridization revealing the presence of $\mathrm{Y} 1$ receptor expression in osteoblasts on endocortical and cancellous surfaces within the femoral bone tissue (Lundberg et al. 2007). NPY is also expressed in osteoblasts and osteocytes, and expression is reduced in vitro by mechanical loading (Baldock et al. 2009, Igwe et al. 2009). Moreover, NPY replacement in the hypothalamus of NPY null mice was only able to partially correct the bone anabolic phenotype (Baldock et al. 2009). No additive effects on bone metabolism were observed in mice deficient for both the $\mathrm{Y} 1$ and $\mathrm{Y} 2$ receptors, indicating that $\mathrm{Y} 1$ and $\mathrm{Y} 2$ receptors may act at different points along a common signaling pathway to control bone formation (Lundberg et al. 2007). In this manner, local NPY actions, via Y1 receptors in the osteoblast, may enable load-appropriate fine tuning of efferent NPY signals involving hypothalamic Y2 receptors. Thus, the NPY system represents a coordinated system, which is not only acting from the brain to the cells of bone, but also interacting with powerful energy homeostatic processes to modulate the relationship between body weight and bone mass (Fig. 4).

\section{The cannabinoid receptors}

Indicating a diversity of central pathways to bone, yet another system, involving endocannabinoid signaling has been elucidated. The endocannabinoid system mediates its actions via two cannabinoid receptors, CB1 and CB2 (Howlett et al. 2002). CB1 is primarily

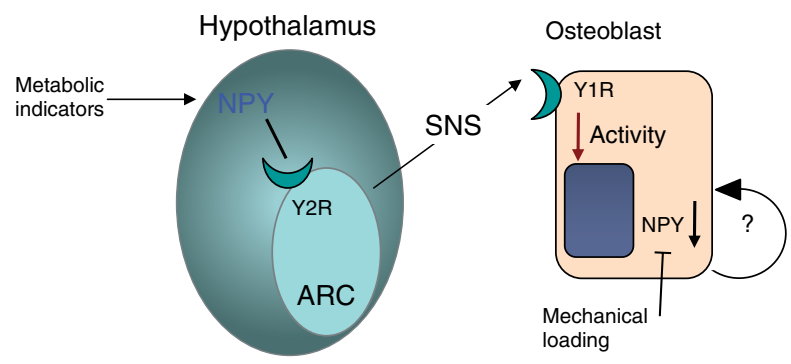

Figure 4 Model of NPY signaling for the regulation of bone formation. Neuropeptide $Y$ signals in the hypothalamus via $Y 2$ receptors inhibit the function of osteoblasts. $Y 1$ receptors expressed on osteoblasts also inhibit osteoblast activity. The local role of osteoblastic NPY, which is inhibited by mechanical loading, is yet to be determined. 


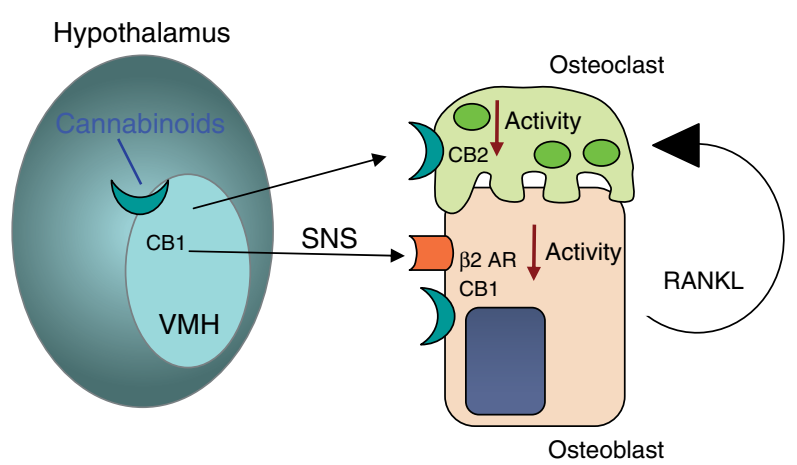

Figure 5 Model of cannabinoids signaling for the regulation of bone formation. The cannabinoid receptor 1 (CB1) is distributed in brain areas associated with motor control, energy, and bone homeostasis and in the periphery in osteoblasts. The CB2 receptor is mainly expressed in the peripheral tissues like osteoclasts but also osteoblasts and osteocytes. The contribution of central vs peripheral $\mathrm{CB} 1$ and $\mathrm{CB} 2$ receptors in mediating the effect of cannabinoids on bone remains to be determined.

found within the central nervous system (CNS) and accounts for most of the CNS actions of cannabinoid drugs and endocannabinoids (Mackie 2008), while CB2 is predominantly expressed in peripheral tissues (Tam et al. 2008). The main CB1 and CB2 endogenous ligands are 2-arachidonoylglycerol and $\mathrm{N}$-arachidonoylethanolamine (Devane et al. 1992, Mechoulam et al. 1995).

Recent independent studies indicated that endocannabinoids regulate bone homeostasis by modulating adrenergic signaling. CB1 receptor signaling activation on presynaptic nerve terminals in bone inhibits norepinephrine release by sympathetic neurons, thus balancing the tonic sympathetic restrain of bone formation (Ishac et al. 1996, Niederhoffer et al. 2003). However, inactivating CB1 receptor increased bone mineral density and additionally provided protection against ovariectomy-induced bone loss (Idris et al. 2005). Furthermore, CB1 receptor antagonism inhibited osteoclast formation and bone resorption, while CB1 knockout mice were resistant to these effects. Thus, cannabinoid signaling, acting via the CB1 receptor, regulates osteoclasts (Idris et al. 2005).

CB2 receptor is expressed in osteoblasts, osteocytes, and osteoclasts. CB2 null mice have accelerated agerelated cancellous bone loss and cortical expansion due to increased bone turnover (Ofek et al. 2006). These results are supported by human genetic association studies linking CNR2 gene (encoding CB2) and reduced bone mass in women (Karsak et al. 2005, Yamada et al. 2007) and in vitro pharmacological studies demonstrating a direct activation of CB2 in osteoclasts. These in vitro studies indicate that CB2 signaling contributes to the maintenance of bone mass by two mechanisms: i) stimulating stromal cells/osteoblasts directly; and ii) inhibiting monocytes/osteoclasts osteoblast/stromal cell RANKL expression both directly and indirectly. The fact that CB2 agonists, which are not psychoactive, attenuate ovariectomyinduced bone loss in mice also suggests that these compounds might be adapted for the treatment of low bone mass diseases (Ofek et al. 2006). Jointly, these data suggest that the cannabinoid system plays an important role in the regulation and maintenance of bone mass through the signaling of both the central and skeletal cannabinoid receptors. This system, in keeping with the NPY system above, highlights the importance of centrally expressed receptors, but also the locally expressed receptors in bone. Importantly, the notion of integrated central and local aspects of these pathways indicates the requirement for feedback. The identification of such agents remains one of the most critical aspects of this work (Fig. 5).

\section{Conclusion}

The simultaneous maintenance of bone mass, mechanical integrity, and mineral homeostasis by the process of bone remodeling requires a complex regulatory milieu. It is now well appreciated that efferent neural signals, involving for the most part of the hypothalamus, play an important role in this regulation. These neural signals convey rapid and often marked effects on osteoblast and osteoclast activity, and thus present tempting therapeutic potential. In addition, these pathways are also highlighting a level of interaction between skeletal tissue and other organ systems, which has, until now, remained unappreciated. Interestingly, this work is revealing crosstalk between other metabolic processes, including energy regulation, but also has the potential to involve higher brain functions. The future promises to reveal a skeletal system far more complex than simply a structural entity, but rather a system of organs integrated with many others throughout the body.

\section{Declaration of interest}

The authors declare that there is no conflict of interest that could be perceived as prejudicing the impartiality of the review reported.

\section{Funding}

This review was funded in part by the National Heath and Medical Research Program Grants 276412, 376028, and 427632. PAB is supported by a fellowship from the NHMRC.

\section{Acknowledgements}

The authors would like to thank Prof. Patrick Bradley for his insight during the production of this manuscript. 


\section{References}

Ahn JD, Dubern B, Lubrano-Berthelier C, Clement K \& Karsenty G 2006 Cart overexpression is the only identifiable cause of high bone mass in melanocortin 4 receptor deficiency. Endocrinology 147 3196-3202. (doi:10.1210/en.2006-0281)

Allison SJ, Baldock P, Sainsbury A, Enriquez R, Lee NJ, Lin EJ, Klugmann M, During M, Eisman JA, Li M et al. 2006 Conditional deletion of hypothalamic Y2 receptors reverts gonadectomyinduced bone loss in adult mice. Journal of Biological Chemistry 281 23436-23444. (doi:10.1074/jbc.M604839200)

Baldock PA, Sainsbury A, Couzens M, Enriquez RF, Thomas GP, Gardiner EM \& Herzog H 2002 Hypothalamic Y2 receptors regulate bone formation. Journal of Clinical Investigation 109 915-921. (doi:10.1172/JCI14588)

Baldock PA, Sainsbury A, Allison S, Lin EJ, Couzens M, Boey D, Enriquez R, During M, Herzog H \& Gardiner EM 2005 Hypothalamic control of bone formation: distinct actions of leptin and Y2 receptor pathways. Journal of Bone and Mineral Research 20 1851-1857. (doi:10.1359/JBMR.050523)

Baldock PA, Allison S, McDonald MM, Sainsbury A, Enriquez RF, Little DG, Eisman JA, Gardiner EM \& Herzog H 2006 Hypothalamic regulation of cortical bone mass: opposing activity of Y2 receptor and leptin pathways. Journal of Bone and Mineral Research 21 1600-1607. (doi:10.1359/jbmr.060705)

Baldock PA, Allison SJ, Lundberg P, Lee NJ, Slack K, Lin EJ, Enriquez RF, McDonald MM, Zhang L, During MJ et al. 2007 Novel role of Y1 receptors in the coordinated regulation of bone and energy homeostasis. Journal of Biological Chemistry 282 19092-19102. (doi:10.1074/jbc.M700644200)

Baldock PA, Lee NJ, Driessler F, Lin S, Allison S, Stehrer B, Lin EJ, Zhang L, Enriquez RF, Wong IP et al. 2009 Neuropeptide Y knockout mice reveal a central role of NPY in the coordination of bone mass to body weight. PLoS ONE 4 e8415. (doi:10.1371/journal. pone.0008415)

Balthasar N, Coppari R, McMinn J, Liu SM, Lee CE, Tang V, Kenny CD, McGovern RA, Chua SC Jr, Elmquist JK et al. 2004 Leptin receptor signaling in POMC neurons is required for normal body weight homeostasis. Neuron 42 983-991.

Bernet F, Dedieu JF, Laborie C, Montel V \& Dupouy JP 1998 Circulating neuropeptide $\mathrm{Y}$ (NPY) and catecholamines in rat under resting and stress conditions. Arguments for extra-adrenal origin of NPY, adrenal and extra-adrenal sources of catecholamines. Neuroscience Letters 250 45-48. (doi:10.1016/S0304-3940(98)00454-6)

Blomqvist AG \& Herzog H 1997 Y-receptor subtypes - how many more? Trends in Neurosciences 20 294-298. (doi:10.1016/S01662236(96)01057-0)

Boden G, Chen X, Mozzoli M \& Ryan I 1996 Effect of fasting on serum leptin in normal human subjects. Journal of Clinical Endocrinology and Metabolism 81 3419-3423. (doi:10.1210/jc.81.9.3419)

Brighton PJ, Szekeres PG \& Willars GB 2004 Neuromedin U and its receptors: structure, function, and physiological roles. Pharmacological Reviews 56 231-248. (doi:10.1124/pr.56.2.3)

Devane WA, Hanus L, Breuer A, Pertwee RG, Stevenson LA \& Griffin G 1992 Isolation and structure of a brain constituent that binds to the cannabinoid receptor. Science 258 1946-1949. (doi:10.1126/science. 1470919)

Ducy P, Desbois C, Boyce B, Pinero G, Story B, Dunstan C, Smith E, Bonadio J, Goldstein S, Gundberg C et al. 1996 Increased bone formation in osteocalcin-deficient mice. Nature 382 448-452. (doi:10.1038/382448a0)

Ducy P, Amling M, Takeda S, Priemel M, Schilling AF, Beil FT, Shen J, Vinson C, Rueger JM \& Karsenty G 2000 Leptin inhibits bone formation through a hypothalamic relay: a central control of bone mass. Cell 100 197-207. (doi:10.1016/S0092-8674(00) 81558-5)
Elefteriou F, Takeda S, Liu X, Armstrong D \& Karsenty G 2003 Monosodium glutamate-sensitive hypothalamic neurons contribute to the control of bone mass. Endocrinology 144 3842-3847. (doi:10. 1210/en.2003-0369)

Elefteriou F, Takeda S, Ebihara K, Magre J, Patano N, Kim CA, Ogawa Y, Liu X, Ware SM, Craigen WJ et al. 2004 Serum leptin level is a regulator of bone mass. PNAS 101 3258-3263. (doi:10.1073/pnas. 0308744101)

Elefteriou F, Ahn JD, Takeda S, Starbuck M, Yang X, Liu X, Kondo H, Richards WG, Bannon TW, Noda M et al. 2005 Leptin regulation of bone resorption by the sympathetic nervous system and CART. Nature 434 514-520. (doi:10.1038/nature03398)

Hamrick MW, Della-Fera MA, Choi YH, Pennington C, Hartzell D \& Baile CA 2005 Leptin treatment induces loss of bone marrow adipocytes and increases bone formation in leptin-deficient $o b / o b$ mice. Journal of Bone and Mineral Research 20 994-1001. (doi:10. 1359/JBMR.050103)

Howlett AC, Barth F, Bonner TI, Cabral G, Casellas P, Devane WA, Felder CC, Herkenham M, Mackie K, Martin BR et al. 2002 International Union of Pharmacology. XXVII. Classification of cannabinoid receptors. Pharmacological Reviews 54 161-202. (doi:10.1124/pr.54.2.161)

Idris AI, van 't Hof RJ, Greig IR, Ridge SA, Baker D, Ross RA \& Ralston SH 2005 Regulation of bone mass, bone loss and osteoclast activity by cannabinoid receptors. Nature Medicine 11 774-779. (doi:10. 1038/nm1255)

Igwe JC, Jiang X, Paic F, Ma L, Adams DJ, Baldock PA, Pilbeam CC \& Kalajzic I 2009 Neuropeptide Y is expressed by osteocytes and can inhibit osteoblastic activity. Journal of Cellular Biochemistry 108 621-630. (doi:10.1002/jcb.22294)

Ishac EJ, Jiang L, Lake KD, Varga K, Abood ME \& Kunos G 1996 Inhibition of exocytotic noradrenaline release by presynaptic cannabinoid CB1 receptors on peripheral sympathetic nerves. British Journal of Pharmacology 118 2023-2028.

Iwaniec UT, Boghossian S, Lapke PD, Turner RT \& Kalra SP 2007 Central leptin gene therapy corrects skeletal abnormalities in leptin-deficient $o b / o b$ mice. Peptides 28 1012-1019. (doi:10.1016/ j.peptides.2007.02.001)

Karsak M, Cohen-Solal M, Freudenberg J, Ostertag A, Morieux C, Kornak U, Essig J, Erxlebe E, Bab I, Kubisch C et al. 2005 Cannabinoid receptor type 2 gene is associated with human osteoporosis. Human Molecular Genetics 14 3389-3396. (doi:10. 1093/hmg/ddi370)

Kristensen P, Judge ME, Thim L, Ribel U, Christjansen KN, Wulff BS, Clausen JT, Jensen PB, Madsen OD, Vrang N et al. 1998 Hypothalamic CART is a new anorectic peptide regulated by leptin. Nature 393 72-76. (doi:10.1038/29993)

Lauzurica N, Garcia-Garcia L, Pinto S, Fuentes JA \& Delgado M 2010 Changes in NPY and POMC, but not serotonin transporter, following a restricted feeding/repletion protocol in rats. Brain Research 1313 103-112. (doi:10.1016/j.brainres.2009.11.075)

Lin S, Boey D, Couzens M, Lee N, Sainsbury A \& Herzog H 2005 Compensatory changes in $\left[{ }^{125} \mathrm{I}\right]$-PYY binding in Y receptor knockout mice suggest the potential existence of further $\mathrm{Y}$ receptor(s). Neuropeptides 39 21-28. (doi:10.1016/j.npep.2004.10.002)

Lundberg P, Allison SJ, Lee NJ, Baldock PA, Brouard N, Rost S, Enriquez RF, Sainsbury A, Lamghari M, Simmons P et al. 2007 Greater bone formation of Y2 knockout mice is associated with increased osteoprogenitor numbers and altered $\mathrm{Yl}$ receptor expression. Journal of Biological Chemistry 282 19082-19091. (doi:10.1074/jbc.M609629200)

Mackie K 2008 Signaling via CNS cannabinoid receptors. Molecular and Cellular Endocrinology 286 S60-S65. (doi:10.1016/j.mce.2008.01.022)

Mechoulam R, Ben-Shabat S, Hanus L, Ligumsky M, Kaminski NE \& Schatz AR 1995 Identification of an endogenous 2-monoglyceride, present in canine gut, that binds to cannabinoid receptors. Biochemical Pharmacology 50 83-90. (doi:10.1016/00062952(95)00109-D) 
Niederhoffer N, Schmid K \& Szabo B 2003 The peripheral sympathetic nervous system is the major target of cannabinoids in eliciting cardiovascular depression. Naunyn-Schmiedeberg's Archives of Pharmacology 367 434-443. (doi:10.1007/s00210-0030755 -y)

Ofek O, Karsak M, Leclerc N, Fogel M, Frenkel B, Wright K, Tam J, Attar-Namdar M, Kram V, Shohami E et al. 2006 Peripheral cannabinoid receptor, CB2, regulates bone mass. PNAS 103 696-701. (doi:10.1073/pnas.0504187103)

Sainsbury A, Schwarzer C, Couzens M \& Herzog H 2002 Y2 receptor deletion attenuates the type 2 diabetic syndrome of $o b / o b$ mice. Diabetes 51 3420-3427. (doi:10.2337/diabetes. $51.12 .3420)$

Sato S, Hanada R, Kimura A, Abe T, Matsumoto T, Iwasaki M, Inose H, Ida T, Mieda M, Takeuchi Y et al. 2007 Central control of bone remodeling by neuromedin U. Nature Medicine 13 1234-1240. (doi:10.1038/nm1640)

Takeda S, Elefteriou F, Levasseur R, Liu X, Zhao L, Parker KL, Armstrong D, Ducy P \& Karsenty G 2002 Leptin regulates bone formation via the sympathetic nervous system. Cell 111 305-317. (doi:10.1016/S0092-8674(02)01049-8)
Tam J, Trembovler V, Di Marzo V, Petrosino S, Leo G, Alexandrovich A, Regev E, Casap N, Shteyer A, Ledent C et al. 2008 The cannabinoid $\mathrm{CB} 1$ receptor regulates bone formation by modulating adrenergic signaling. FASEB Journal 22 285-294. (doi:10.1096/ fj.06-7957com)

Wolf G 2008 Energy regulation by the skeleton. Nutrition Reviews 66 229-233. (doi:10.1111/j.1753-4887.2008.00027.x)

Yadav VK, Oury F, Suda N, Liu ZW, Gao XB, Confavreux C, Klemenhagen KC, Tanaka KF, Gingrich JA, Guo XE et al. 2009 A serotonin-dependent mechanism explains the leptin regulation of bone mass, appetite, and energy expenditure. Cell 138 976-989. (doi:10.1016/j.cell.2009.06.051)

Yamada Y, Ando F \& Shimokata H 2007 Association of candidate gene polymorphisms with bone mineral density in community-dwelling Japanese women and men. International Journal of Molecular Medicine 19 791-801.

Received in final form 6 July 2010

Accepted 26 July 2010

Made available online as an Accepted Preprint 26 July 2010 